\title{
REKONSTRUKSI 3D LANDMARK MEMVISUALISASIKAN PERKAMPUNGAN PERADABAN KUNO SITUS LIYANGAN TEMUAN BALAI ARKEOLOGI YOGYAKARTA
}

\author{
Agnes Karina Pritha Atmani \\ No.Tlp.: +62813-80915096, E-mail: agneskarina@isi.ac.id \\ Mohammad Arifian Rohman \\ No. Tlp.: +6287823395707 $\square$, E-mail: arifian@isi.ac.id \\ Program Stud D-3 Animasi, Fakultas Seni Media Rekam \\ Institut Seni Indonesia Yogyakarta \\ Jalan Parangtritis Km, 6,5 Sewon, Bantul, Daerah Istimewa Yogyakarta 55188
}

\begin{abstract}
ABSTRAK
Artefak fisik dan hasil temuan arkeologis dapat dipindai secara 3D menggunakan perangkat pemindai, yaitu $3 D$ Terrestrial Laser Scanning (TLS), berbasis foto dengan teknik photogrammetry. Sistem kerjanya sebatas memindai kondisi situs saat itu dan harganya masih mahal. Balai Arkeologi menghadirkan kondisi situs pada zaman situs sebagai bangunan yang sakral atau dilihat dari aspek fungsinya. Tujuan penelitian adalah menghadirkan kembali kondisi situs seperti pada masa kejayaannya dengan menggunakan metode visualisasi 3D. Objek penciptaan dan proses rekonstruksi 3D landmark dari data arkeologis Balai Arkeologi DIY dan Situs Liyangan, Temanggung, Jawa Tengah. Proses rekonstruksi 3D dibantu peneliti Balai Arkeologi DIY supaya objektivitas dan validitas data terjaga secara keilmuan. Proses penciptaan dengan permodelan aset, tekstur, dan perancangan tata letak. Produksi rekonstruksi $3 D$ menggunakan perangkat lunak 3Ds Max dan mesin game Unreal sebagai penyaji antarmuka akses bagi pengguna berikut interaksinya, kemudian dilakukan evaluasi pengujian berdasarkan sisi persepsi arkeologi. Hasil evaluasi, situs liyangan dinyatakan lebih tua daripada situs yang ada di sekitarnya, terbukti adanya situs yang mendampingi pada era yang sama, antara lain Candi Dharmasala di kompleks Candi Dieng yang belum menerapkan sistem relief seperti Candi Dieng. Hasil pengumpulan data dari buku referensi di Balai Arkeologi dan pengamatan di lapangan, proses rekonstruksi Situs Liyangan dinyatakan berhasil sesuai dengan bukti persepsi arkeologis tersebut. Dengan demikian, hasil akhir yang didapat berupa tercapainya purwarupa rekonstruksi 3D landmark Situs Liyangan.
\end{abstract}

Kata Kunci: rekonstruksi, 3D Landmark, Situs Liyangan

\begin{abstract}
Physical artifacts and archaeological findings can be scanned 3D using a scanner device, namely $3 D$ Terrestrial Laser Scanning (TLS), based on photos with photogrammetry techniques. The system worked as limited as scanning the condition of the site at that time, and it was still expensive. The Archaeological Hall presents the condition of the site in the era of the site as a sacred building or seen from the aspect of its function. The purpose of the research is to bring back the condition of the site as in its heyday by using $3 D$ visualization methods. Objects of creation and the process of $3 D$ reconstruction of landmarks from archaeological data of diy archaeological hall and liyangan site, Temanggung, Central Java. The process of $3 D$ reconstruction is assisted by diy archaeological researchers, so that the objectivity and validity of the data are maintained scientifically. The process of creation by modeling assets, textures, and layout design. The production of $3 D$ reconstruction uses 3Ds Max software and unreal game engine as presenters of access interfaces for users and their interactions, then conducted testing evaluations based on archaeological perception. The results of the evaluation, liyangan site is declared older than the site in the vicinity, proven the existence of sites that accompany in the same era, among others Dharmasala temple in dieng temple complex that has not implemented a relief system such as Dieng temple. The results of data collection from reference books in the Archaeological Hall and observations in the field, the liyangan site reconstruction process was declared successful according to the evidence of archaeological perception, so that the final results obtained in the form of prototypes of $3 D$ reconstruction of liyangan site landmarks were achieved.
\end{abstract}

Keywords: Reconstruction, 3D Landmarks, Liyangan Sites 


\section{PENDAHULUAN}

Kondisi pandemi COVID-19 yang melanda dunia sejak tahun 2020 sampai saat ini belum juga usai. Tempat edukasi publik seperti halnya perpustakaan umum dan museum memiliki keterbatasan akses baik dalam jumlah pengunjung maupun akses dokumen tertentu. Para pustakawan mulai berinovasi dengan melakukan alih media buku-buku fisik menjadi dokumen digital baik dengan cara yang sederhana seperti melakukan pemindaian digital, transliterasi dokumen berbahasa asing, dan dokumen kuno, bahkan ada yang melakukan alih media teks menjadi audio dengan berbantukan perangkat lunak tertentu.

Data berwujud artefak di museum atau masih berada di area situs purbakala, seperti candi dan situs-situs arkeologi lainnya, membutuhkan keahlian tambahan atau bantuan pihak lain sebagai pengalih media benda-benda tersebut menjadi digital. Hal ini supaya dapat dinikmati secara maya oleh para pelajar selama melakukan pembelajaran daring.

Artefak fisik dan hasil temuan arkeologis lainnya dapat dipindai secara tiga dimensi dengan menggunakan perangkat pemindai 3D, baik yang berbasis foto dengan teknik photogrammetry maupun perangkat pindai laser seperti $3 D$ Terrestrial Laser Scanning (TLS). Namun, alat pindai 3D berbasis laser masih sangat mahal sehingga tidak semua Balai Arkeologi di Indonesia memilikinya dan alat tersebut hanya sebatas memindai kondisi situs pada saat itu atau kondisi yang dijumpai masa sekarang, kemudian bagaimana menghadirkan kondisi situs pada masa lalu seperti sedia kala yang terjadi pada zaman situs tersebut menjadi bangunan yang sakral atau dilihat dari aspek fungsinya. Balai Arkeologi masih mengandalkan data foto berikut deskripsinya untuk menunjukkan dimensi, lokasi, dan keadaan artefak tersebut dari waktu ditemukan sampai pada saat dipajang di museum. Data tersebut masih sangat terbatas dan hanya dapat disaksikan jika pengunjung secara langsung berada di lokasi.

Perkembangan perangkat lunak permodelan tiga dimensi sudah berkembang dengan hasil yang sangat realistis. Rekonstruksi sebuah benda maya dapat disajikan seolah-olah nyata secara fisik. Realitas maya ini mampu menjadi jembatan bagi para ahli rekonstruksi realitas maya untuk berperan di industri hiburan ataupun bidang keilmuan lain yang membutuhkannya khususnya di bidang keilmuan Arkeologi. Seperti halnya permasalahan dalam keterbatasan info dan penyajian artefak secara digital, para rekonstruktor maya mampu menjadi pembangkit data digital tiga dimensi dari artefak yang telah ditemukan berdasarkan info dari arkeolog. Data temuan saintifik secara arkeologis dapat dibangkitkan dalam realitas maya dengan lebih nyata dan informatif.

Tujuan sebuah penelitian penciptaan realitas maya secara tiga dimensi dengan memperhitungkan data hasil temuan arkeologis dari Balai Arkeologi Yogyakarta. Studi kasus yang menjadi dasar penciptaan adalah Situs Liyangan di Temanggung, Jawa Tengah. Balai Arkeologi Yogyakarta memiliki area penelitian di wilayah Jawa Tengah, DIY, dan Jawa Timur.

Keunikan dari penelitian ini adalah untuk menghadirkan kondisi situs pada masa lalu seperti sedia kala yang terjadi pada zaman situs tersebut menjadi bangunan yang sakral atau dilihat dari aspek fungsinya, proses penciptaan seni terkait ambiance yang dihadirkan dari masa lalu hanya dapat diproduksi dengan melalui tahap penciptaan visual 3D (tiga dimensi).

Rekonstruksi tiga dimensi yang dihasilkan memiliki nilai urgensi yang sangat tinggi sebagai sumbangsih karya cipta bidang animasi dalam hubungannya secara interdisipliner dengan bidang arkeologi yang diwakili oleh Balai Arkeologi Yogyakarta selaku mitra stakeholder Program Studi Animasi, FSMR, ISI Yogyakarta dan karya cipta penelitian ini dapat mendukung Mata Kuliah Permodelan dan Tekstur 3D pada Program Studi Animasi, FSMR, ISI Yogyakarta. Karya cipta ini diharapkan juga dapat mewujudkan kemudahan akses informasi tentang budaya peradaban kuno peninggalan leluhur bangsa Indonesia di Situs Liyangan, Temanggung, Jawa Tengah sebelum 
terjadinya bencana letusan gunung berapi Sindoro. Rekonstruksi 3D dapat dilihat citra relief gajah bisa menghasilkan permukaan 3D yang lebih baik. Bentuk reliefnya lebih sederhana dengan sebaran gelap terang yang lebih merata, kedalaman relief yang relatif dekat, dan tidak mempunyai lekukan rumit dari permukaan hingga ke dasar relief. Hasil dari penambahan tekstur citra candi ke atas objek rekonstruksi mempunyai sedikit lubang dihasilkan citra relief gajah. Terdapat beberapa kelebihan dan kekurangan dari metode rekonstruksi 3D yang digunakan ini untuk objek relief candi. Beberapa kelebihannya adalah komputasi lebih sederhana dan cukup menggunakan satu sumber citra 2D. Selain itu, juga mempunyai beberapa kekurangan, seperti metode belum dikemas dalam satu aplikasi yang mudah dalam pengoperasiannya dan asumsi kedalaman belum tepat saat diterapkan pada relief candi yang mempunyai lekukan permukaan yang sangat bervariasi. Selain itu, relief yang dapat direkonstruksi menjadi 3D terbatas pada jenis relief yang mempunyai lekukan permukaan yang hampir seragam dan warna tekstur tidak banyak berbeda (Tiga et al., 2010)

Kehadiran dunia maya mengubah perilaku pencarian dan akses informasi. Repositori data digital menjadi solusi pelestarian data fisik atau material kuno dan sekaligus sebagai wahana penyimpanan data yang tepercaya dalam jangka waktu yang lama. Kemudahan akses informasi khusus tentang pelestarian budaya juga sudah menjadi perhatian khusus UNESCO (United Nations Educational, Scientific, and Cultural Organization) sejak 17 Oktober 2003 dalam sebuah piagam perjanjian khusus tentang pelestarian data budaya secara digital yang masih digunakan sampai saat ini. UNESCO berpendapat tentang pentingnya pelestarian budaya dan digitalisasi dokumen kuno demi generasi masa depan terlebih jika disinyalisasi masyarakat budaya tersebut sudah akan punah. Piagam UNESCO mendefinisikan warisan digital melingkupi budaya, pengajaran, sumber daya ilmiah, dan administrasi seperti teknis, medis, dan informasi lainnya yang dibuat secara digital atau yang diubah dari analog menjadi digital dalam bentuk teks, basis data, foto, video, audio, grafik, perangkat lunak, dan halaman web (Lusenet, 2007). Definisi ini melibatkan material warisan tak benda ke dalamnya yang sebelumnya tidak ada sehingga sangat penting dijadikan dasar untuk melakukan revolusi digital dalam kegiatan pelestarian warisan budaya di Indonesia.

\section{Pusat Penelitian Arkeologi Nasional} (Arkenas) menjadi garis depan lembaga pemerintah yang khusus mengelola penelitian dan informasi berkaitan dengan temuan arkeologi di Indonesia. Arkenas memiliki potensi menjadi salah satu lembaga strategis dan tepercaya sebagai sumber penyaji informasi yang valid mengenai temuan dan pengetahuan arkeologi di Indonesia. Dengan demikian, informasi yang dikeluarkan oleh Arkenas dibantu Balai Arkeologi (Balar) yang tersebar di 10 wilayah Indonesia akan menjadi rujukan utama pengetahuan arkeologi Indonesia. Peran penting ini selama ini telah direspons baik oleh Arkenas dengan rencana strategis (renstra) yang dikembangkan selama periode lima tahunan. Pada periode 20202024 Rencana Strategis Pusat Penelitian Arkeologi Nasional memiliki kebijakan publik berbasis riset yang dijabarkan dalam Gambar 1 (Nasional, 2020).

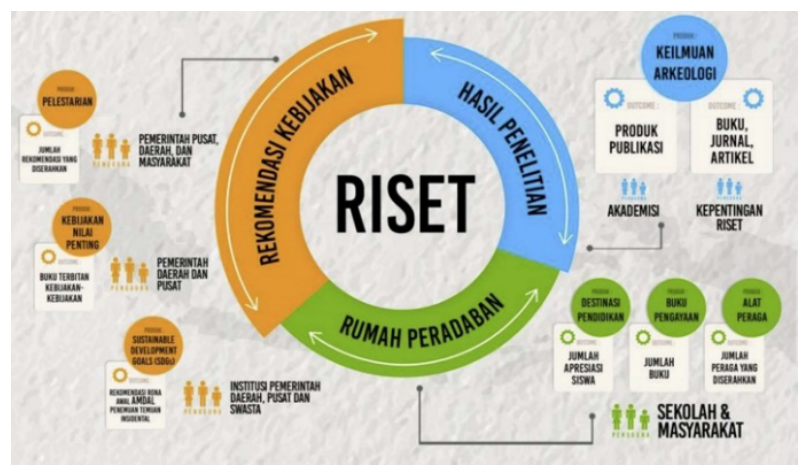

Gambar 1 Kebijakan publik berbasis riset pada rencana strategis Arkenas 2020-2024 (Sumber: Dokumen Rencana Strategis Pusat Penelitian Arkeologi Nasional 2020-2024, 2020).

Strategi literasi digital dipandang sebagai sebuah salah satu cara alih wahana informasi bagi abad ini. Era revolusi industri 4 turut membawa perubahan perilaku manusia dalam mencari, mengolah, dan menyebarkan informasi. Generasi 
saat ini lebih menyukai mengonsumsi informasi secara digital dibandingkan dengan membaca buku. Informasi visual menjadi penting saat pilihan alih wahana media informasi dilakukan. Dengan demikian, ragam penyajian informasi secara digital berdasarkan fungsi dan perannya dapat disusun sebagai sebuah ekosistem baru literasi arkeologi Indonesia pada kemudian hari.

Rekonstruksi identitas ke"tionghoa'an dalam film indie Pasca-Suharto memberikan gambaran yang kompleks dan membantu dalam menafsirkan makna-makna yang terkandung dalam karya film indie sebagai suatu hasil produksi dan reproduksi dari gambaran kehidupan masyarakat Tionghoa sebenarnya. Sebuah rekonstruksi mampu memberikan gambaran kehidupan pada masanya (Rokhani et al., 2016).

Rekonstruksi visual lainnya yang mampu menginspirasi penelitian ini adalah penggunaan perekaman fotografi, untuk mendukung pola rekonstruksi visual Sarip Tambak Oso. Sebuah rekonstruksi tahapan cerita rakyat yang hilang, yang kemudian dimunculkan dalam bentuk serial fotografi yang saling berurutan. Kegunaan rekonstruksi fotografi ini untuk memudahkan dalam membaca atau mengembangkan cerita rakyat sebagai satu kesatuan yang dapat dilihat secara saksama (Wibisono et al., 2021).

Inspirasi lainnya berasal dari proyek Gabii di Italia yang merupakan proyek arkeologi internasional yang diinisiasi oleh Nicola Terrenato, University of Michigan. Penelitian ini mampu menyinergikan temuan lapangan eskavasi di situs Gabii dengan perekaman digital tiga dimensi dengan bantuan informasi georeferensi GIS sehingga dapat dibangun sebuah basis data visual dengan bentuk visual tiga dimensi (3D) yang interaktif (Rachel Opitz, 2018) (R. Opitz et al., 2018).

Salah satu contoh pembangunan basis data digital sebagai sebuah strategi konservasi budaya dan arkeologi dapat dilihat pada proyek Cultural Repositories and Information Systems (CURIOS) yang merupakan proyek pembangunan basis data budaya yang bekerja sama dengan komunitas pelestari budaya setempat dalam sebuah ekosistem digital yang dibangun bersama di daerah pedesaan Scotlandia (D. Beel et al., 2015) (D. E. Beel et al., 2017).

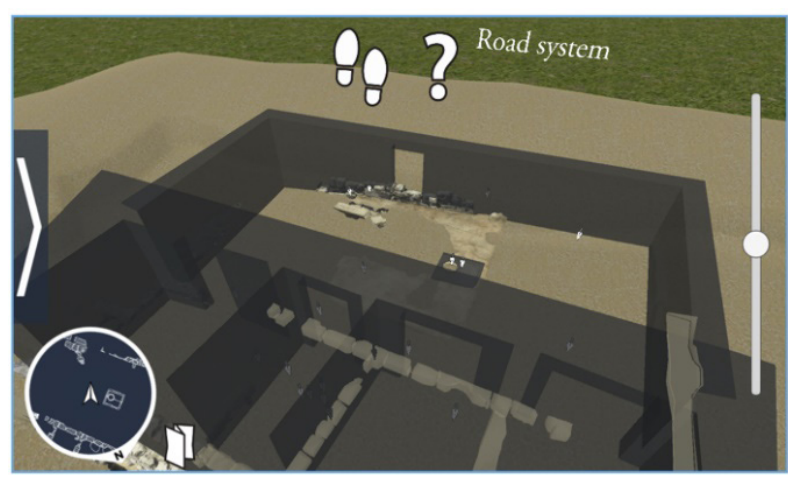

Gambar 2 Tampilan data visual 3D proyek Gabii (Sumber: Aplikasi virtual di https://www.fulcrum.org/ concern/monographs/n009w229r\#webgl, diakses pada

14 November 2020)

KotaAmsterdam juga turut akan dibuat versi digitalnya dengan digitalisasi kota beserta segala bentuk bangunan heritage yang menyertainya agar jika dibutuhkan rekonstruksi ulang dapat dihasilkan ukuran dan bentuk replika yang serupa dengan aslinya. Proyek ini sudah mulai dirancang dengan memulainya secara parsial untuk membangun data digital yang dinamis dengan target akhir produk kota Amsterdam digital yang memiliki perbandingan data yang serupa dengan aslinya (Alberts et al., 2017).

Proyek pemetaan budaya juga telah dilakukan oleh Malaysia dengan Centre for Knowledge and Understanding of Tropical Architecture and Interior (KUTAI) yang mulai membuat beberapa program pembangunan basis data arsitektur bangunan kuno seperti rumah adat di Malaysia dari bentuk pemeleh dengan atap sebagai elemen unik rumah tradisional sampai dengan pendataan dan digitalisasi motif-motif yang ada di arsitektur bangunan kuno (Rashid, 2015). Rumah adat Batak Toba juga pernah dilakukan pemetaan budaya secara digital dengan bantuan teknik fotogrametri close-range dengan hasil data yang beragam, dari gambar foto $2 \mathrm{D}$, titik awan padat 
3D, geometri objek, sampai dengan model 3D solid (Hanan et al., 2015).

Pengalaman realitas maya yang dibangkitkan dari sumber data arkeologi memiliki kesan estetis tersendiri bagi pengakses. Personalisasi yang dialami setiap pengguna akan berbeda dan memberikan aspek pembelajaran mandiri yang termotivasi secara internal. Rasa ingin tahu terbangkitkan dengan setiap interaksi yang dialami. Transmedia objek fisik menjadi maya dengan realitasnya secara multimodal sering menggugah para peneliti arkeologi untuk mewujudkan "kondisi sediakala" saat bangunan kuno ini utuh atau membangkitkan "kesan" seolah-olah mengalami peradaban kuno yang dibangun Kembali (Galani \& Kidd, 2019) (Ioannides \& Quak, 2014) (Agosti et al., 2014).
Dokumentasi yang tepat tentang informasi dan bentuk warisan budaya sangat penting untuk perlindungan dan studi ilmiahnya. Hal ini telah disosialisasikan Balai Arkeologi di Indonesia sesuai wilayah masing-masing, tetapi pembangkitannya secara digital yang mampu dieksplorasi oleh pengunjung secara maya masih belum dijumpai. Dengan demikian, melalui rekonstruksi model 3D yang dihasilkan melalui penelitian ini dapat digunakan untuk dokumentasi digital dan untuk melakukan analisis kemungkinan restorasi virtual sebuah peradaban, peradaban kuno Situs Liyangan seperti halnya yang dibangun oleh Calin di penelitiannya tentang kebudayaan Rumania (Calin et al., 2015). Oleh karena itu, penelitian penciptaan ini akan dilakukan dengan pemetaan alur penelitian seperti pada Gambar 3.

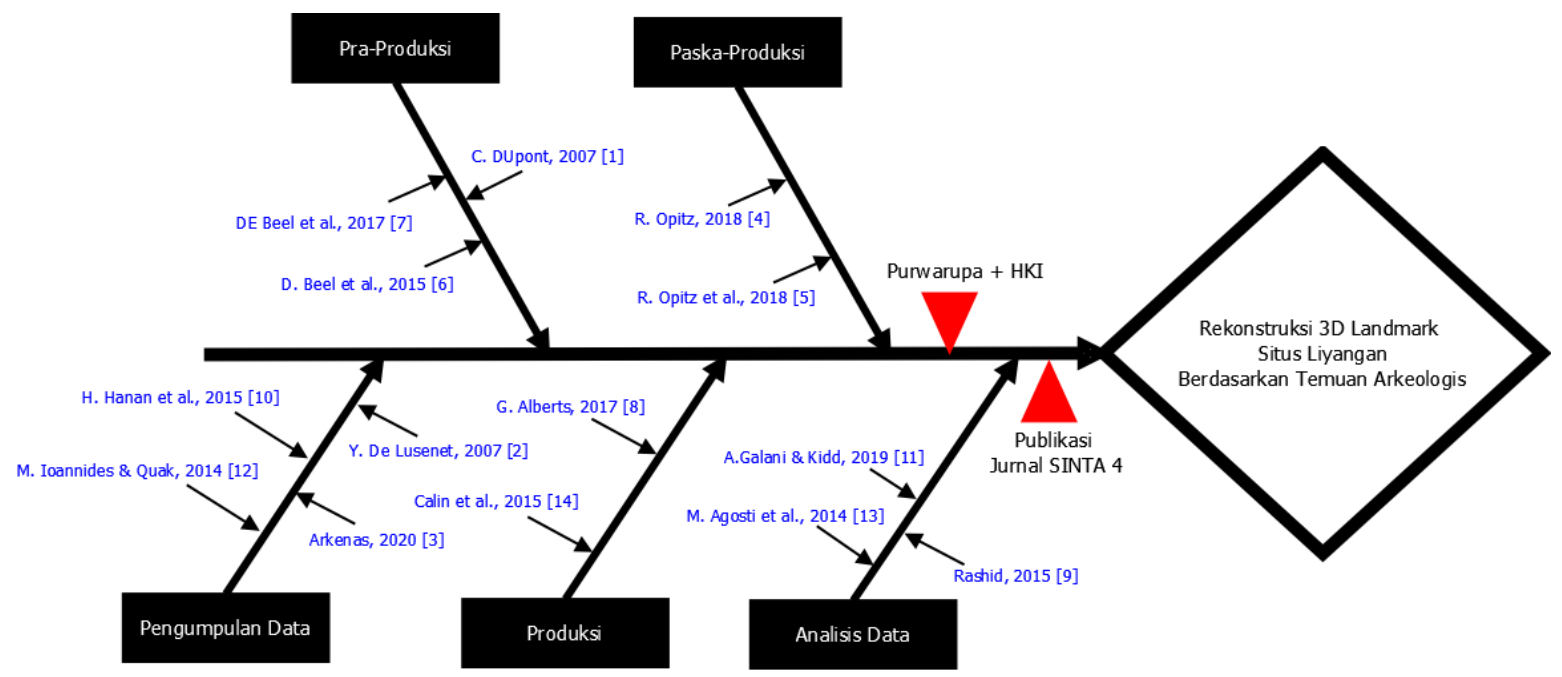

Gambar 3. Pemetaan alur penelitian penciptaan rekonstruksi 3D landmark Situs Liyangan

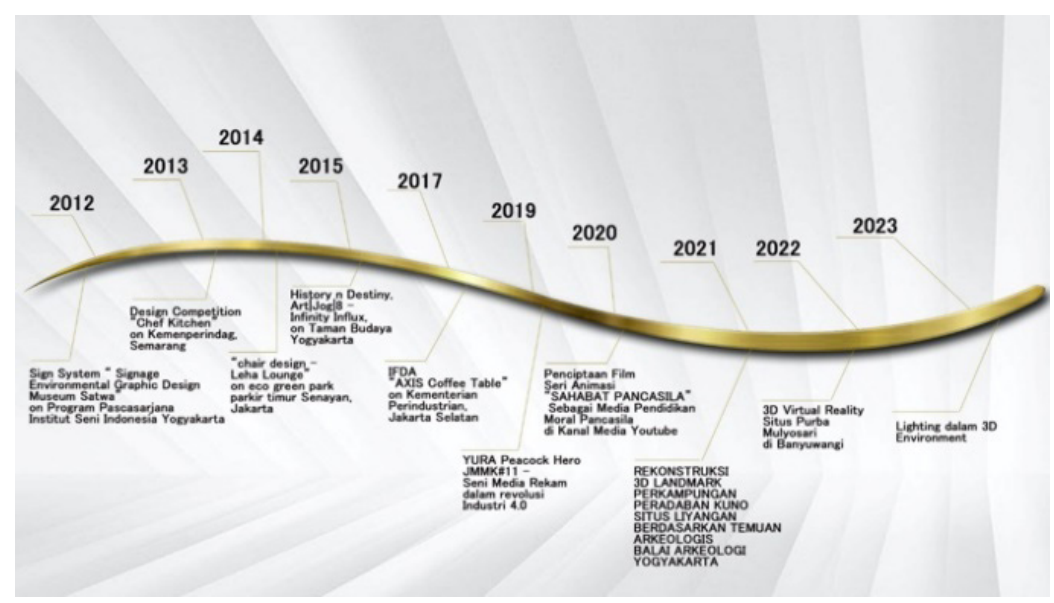

Gambar 4 Road Map penelitian penciptaan seni 
Pemetaan alur penelitian tersebut merupakan struktur tahapan pola produksi yang tersusun dari proses pengumpulan data, praproduksi, produksi, pascaproduksi hingga analisis data yang merupakan unsur penguat dari penciptaan rekonstruksi 3D. Berikut adalah posisi penelitian yang tercantum dalam peta jalan penelitian (road map) dari penulis pada Gambar 4.

Relevansi dari artikel kajian pustaka tersebut memiliki kemiripan pola berpikir dan mengalami perbedaan pada tujuan yang dicapai serta tahapan produksi dari rekonstruksi situs. Dengan demikian, hasil penelitian ini dapat menjadi salah satu ranting dalam pemetaan alur penelitian. "Berdasarkan tinjauan pustaka tersebut, ternyata topik penelitian ini berbeda sehingga penelitian "Rekonstruksi 3D Landmark Perkampungan Kebudayaan Kuno Situs Liyangan Temanggung Berdasarkan Temuan Arkeologis Balai Arkeologi Yogyakarta” ini layak diteruskan.

\section{METODOLOGI PENELITIAN}

Proses penciptaan diawali dengan observasi data arkeologis yang telah diadministrasi oleh Balai Arkeologi Yogyakarta dan kunjungan lapangan di Situs Liyangan, Temanggung, Jawa Tengah. Eksplorasi suasana, kontur tanah, tekstur warna, dan lokasi geografis landmark di Situs Liyangan dilakukan di lokasi temuan arkeologi guna mendapatkan contoh data primer langsung dari kondisi terakhir di lokasi dan mencocokkannya dengan data tertulis yang ada sebagai sebuah bentuk pemutakhiran nuansa rekonstruksi yang akan dibangkitkan secara realitas maya nantinya. Serangkaian proses ini dinamakan sebagai proses pengumpulan data yang tampak pada Gambar 5 .

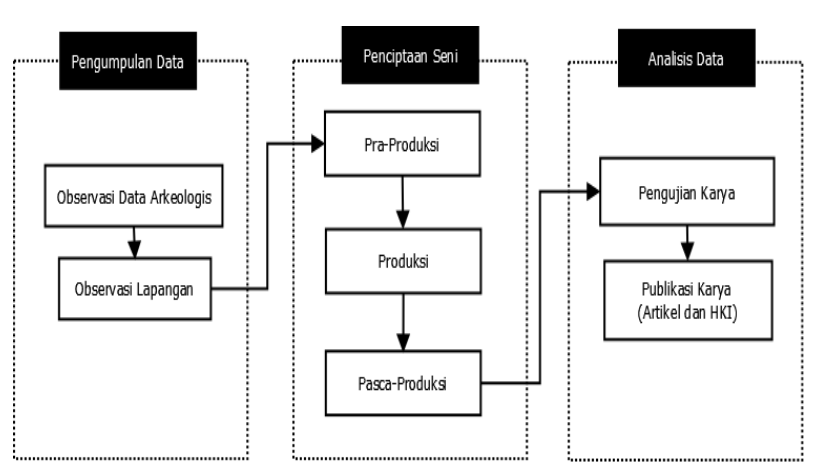

Gambar 5 Metode penelitian penciptaan rekonstruksi

3D landmark peradaban kuno Situs Liyangan

Proses pengambilan data dilakukan dengan pengambilan gambar berupa foto dari situs-situs yang telah ditemukan oleh pihak Balai Arkeologi Yogyakarta di Situs Liyangan. Foto dari situs tersebut akan dipergunakan sebagai acuan dalam proses penciptaan model 3D dan sebagai bahan material yang akan diolah dalam tekstur dan pewarnaan pada objek 3D model situs Liyangan. Hasil dari beberapa foto tersebut dapat dilihat pada Gambar 6 dan Gambar 7.

Setelah proses pengumpulan data, kemudian dilakukan eksplorasi ide awal dalam persiapan awal produksi (praproduksi) yang meliputi pembuatan sketsa kasar (rough), pembuatan file tekstur, pembuatan daftar aset visual, dan pemetaan landmark maya dengan perbandingan 1:1. Persiapan ini dilakukan untuk melakukan verifikasi data yang diperoleh pada proses pengumpulan data sebelum nantinya digunakan dalam proses produksi model 3D. Persiapan ini akan mempercepat proses produksi dan memastikan produksi berjalan lancar dengan minimum revisi di hasil akhirnya nanti. Proses pembuatan aset visual seperti Gambar 8 sampai dengan Gambar 10.

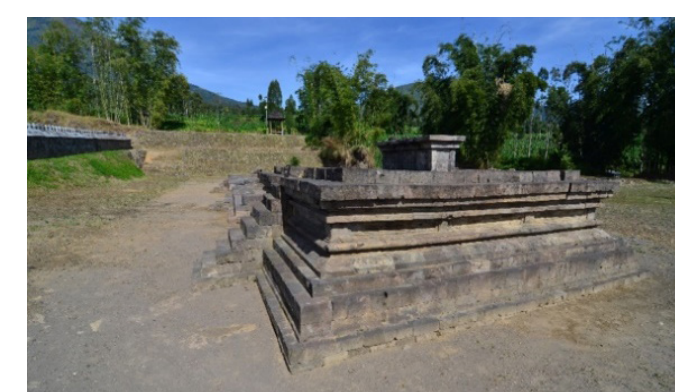

Gambar 6 Situs utama merupakan bangunan candi dalam fungsi peribadatan 


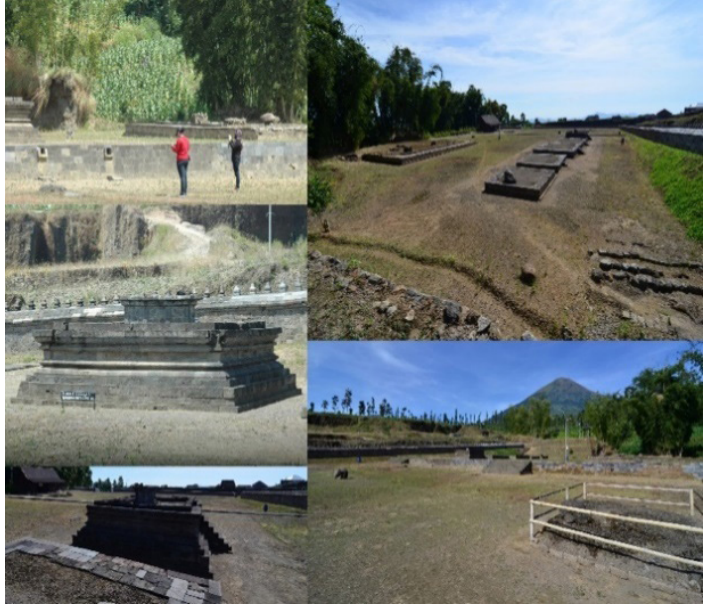

Gambar 7 Kompleks area peribadatan Situs Liyangan
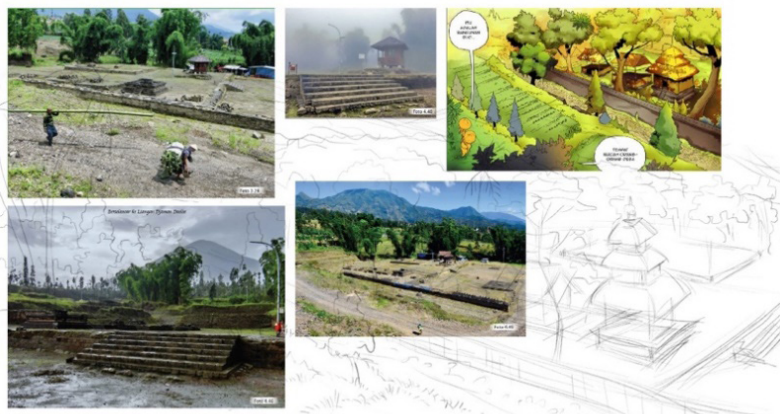

Gambar 8 Pengolahan visual eksplorasi ide awal di area peribadatan di Situs Liyangan

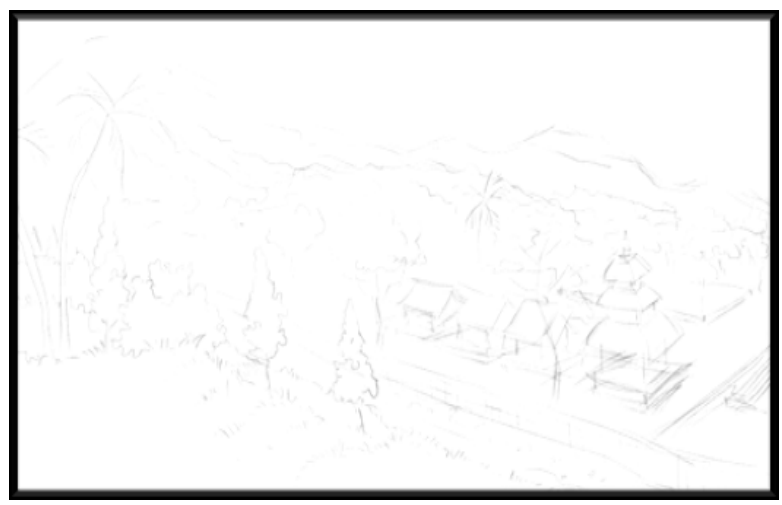

Gambar 9 Pengolahan visual eksplorasi ide awal di area peribadatan di Situs Liyangan

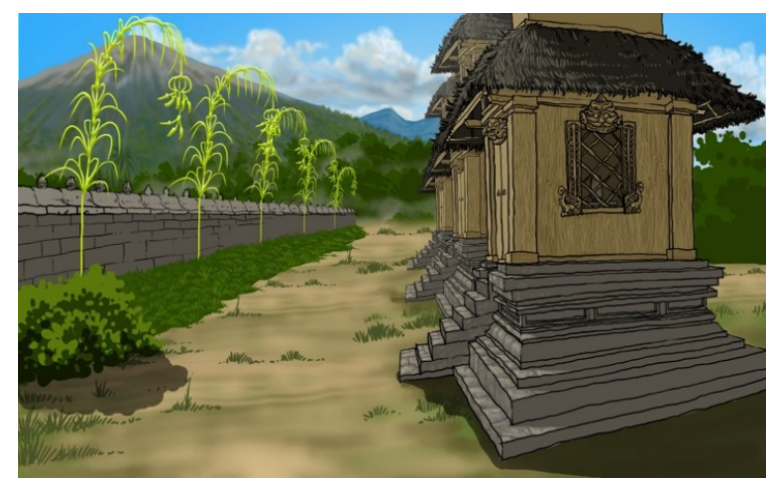

Gambar 10 Pengolahan visual di area peribadatan di Situs Liyangan
Proses produksimeliputi proses pembangunan model tiga dimensi dengan perbandingan 1:1 dan penteksturan. Setelah semua aset yang telah dibangun di realitas maya menggunakan bantuan perangkat lunak game engine Unreal, pengaturan cahaya dan ambien dilakukan secara virtual untuk membangun suasana yang semirip mungkin dengan persepsi visual para arkeolog berdasarkan hasil temuan arkeologi yang didapatkan Balai Arkeologi Yogyakarta. Proses akhir pada tahapan penciptaan seni adalah proses pascaproduksi yang merupakan proses penambahan detail dari hasil rekonstruksi 3D landmark, yaitu dengan penambahan suara dan kontrol kendali interaksi pengguna realitas maya. Hasil akhir dapat dinikmati secara maya dengan bantuan game engine Unreal sebagai media perantara eksplorasi virtual. Tahap awal dalam proses 3D model pada Gambar 11 dan Gambar 12.

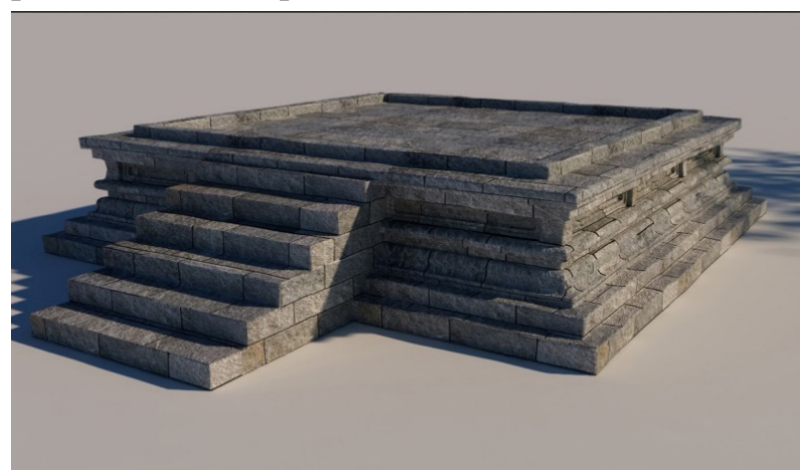

Gambar 11 Proses 3D model pada bangunan peribadatan Situs Liyangan

Setelah karya cipta dihasilkan, lalu masuk pada tahap analisis data dengan pengujian produk baik secara visual, kinerja, maupun validasi data aset 3D yang dibangkitkan secara virtual dipandang dari hasil temuan fisik secara arkeologis. Jika semua data sudah tervalidasi oleh arkeolog dan pengujian dinyatakan berhasil, dilakukan publikasi karya dalam wujud artikel ilmiah di jurnal nasional dan pendaftaran kekayaan intelektual dari produk yang dihasilkan. 


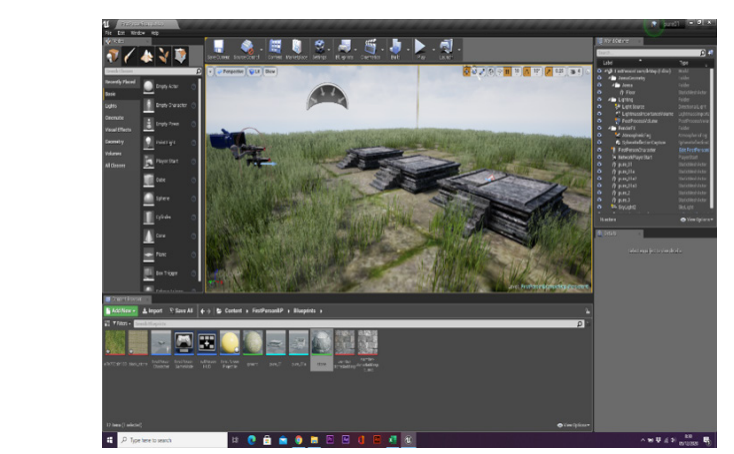

Gambar 12 Proses percobaan layout pada game engine Unreal pada bangunan peribadatan Situs Liyangan

\section{PEMBAHASAN}

Proses perwujudan rekonstruksi 3D Situs Liyangan merupakan tahapan yang cukup rumit dikarenakan hanya terdapat struktur pondasi dari punden peribadatan dan punden pendamping. Berbeda halnya dengan bangunan petirtaan yang telah ditemukan bagian atas dari petirtaan sehingga dapat terlihat wujud dari bangunan tersebut. Struktur rekonstruksi yang terdapat di Situs Liyangan memiliki pola tatanan fisik yang mengandung unsur spiritual terhadap dunia dan lingkungan sekitarnya (Tanudirjo et al., 2019). Situs Liyangan memiliki struktur dan pola yang serupa dengan Situs Dharmasala yang berada di Dieng. Keduanya memiliki struktur fondasi Punden yang berjajar yang berbahan batu, sedangkan di bagian atas merupakan konstruksi kayu dari tiang atau pilar hingga struktur atap serta berdasarkan data atap menggunakan ijuk tebal. Faktor kemiripan struktur dan pola di Situs Liyangan adalah Situs Dharmasala memiliki struktur bangunan dengan terdapatnya umpak batu sehingga bangunan tersebut didominasi oleh unsur kayu. Unsur tersebut menjadi landasan pola berpikir desain dalam rekonstruksi 3D Situs Liyangan.

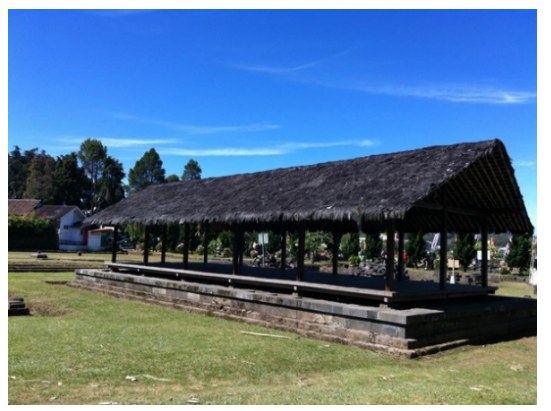

Gambar 13 Situs Dharmasala Dieng, Jawa Tengah
Berbeda dengan komplek percandian corak Hindu di sekitar Jawa Tengah, Jawa Timur, dan Bali yang memiliki atap tingkatan dari pola ganjil tiga, lima, tujuh terutama di bangunan atap peribadatan candi, Situs Liyangan merupakan kompleks spiritual dengan pemujaan Dewa Siwa. Unsur spiritual tersebut dibuktikan dari banyaknya temuan artefak berupa yoni di area sekitar kompleks peribadatan Situs Liyangan baik itu berada di daerah pemukiman maupun di beberapa titik area pertanian. Diasumsikan bahwa bangunan Situs Liyangan di Punden Utama merupakan area yang terbuka karena terdapat yoni yang memiliki ukuran yang panjang serta memiliki tiga lubang yang berfungsi penempatan dari lingga (Tanudirjo et al., 2019).

Temuan-temuan artefak yang menjadi kunci material terhadap rekonstruksi adalah ditemukannya ayaman bambu dan ijuk di sekitar punden dan umpak yang memberikan gambaran bahwa material tersebut digunakan sebagai dinding dan atap. Fakta atas temuan-temuan arkeologi yang dilakukan oleh Balai Arkeologi Yogyakarta menjadi dasar pemikiran akan pola bentuk serta ruang rekonstruksi yang terwujud dalam 3D.

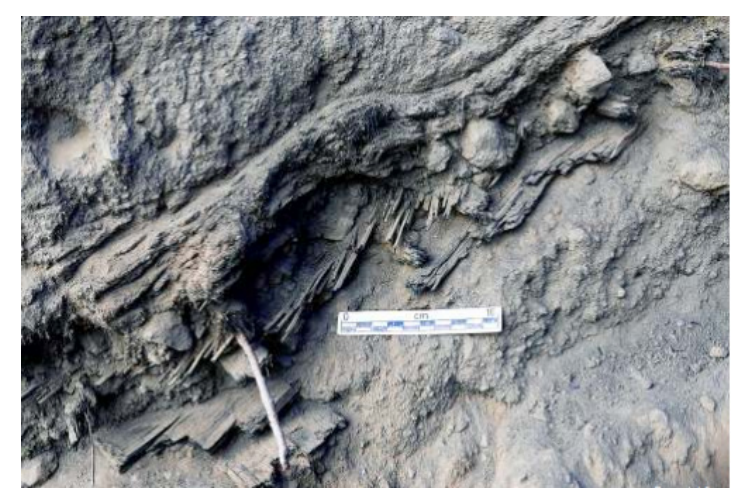

Gambar 14 Anyaman bilah bambu dan tumpukan ijuk yang tersegel oleh material vulkanis 

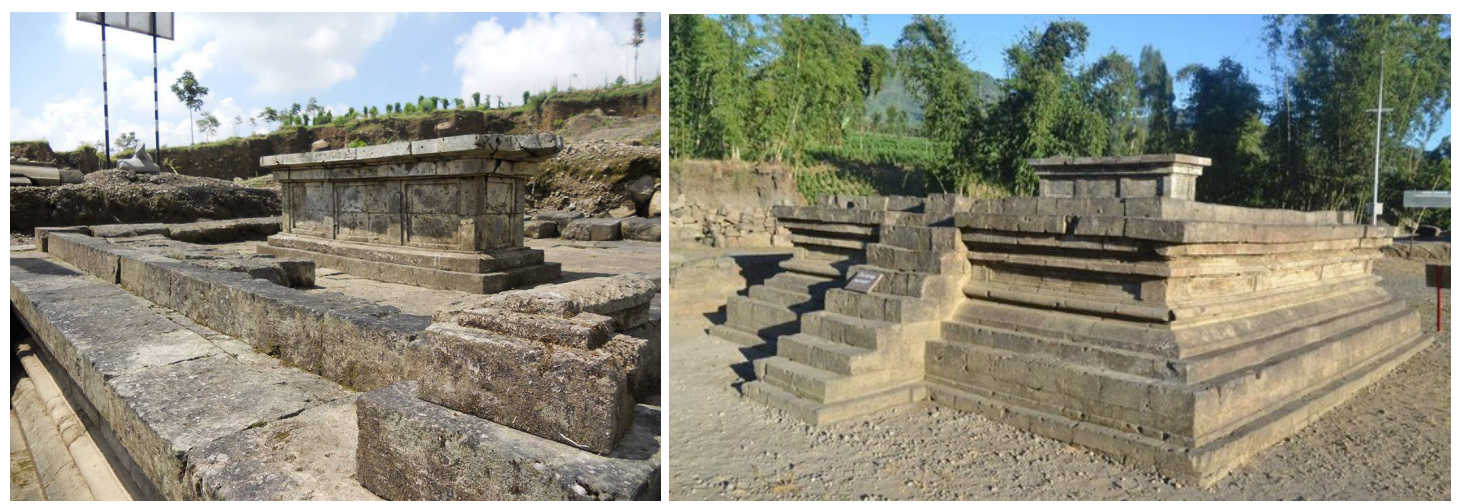

Gambar 15 Terdapat yoni yang memiliki tiga buah lubang

penempatan lingga di atas punden utama peribadatan Situs Liyangan
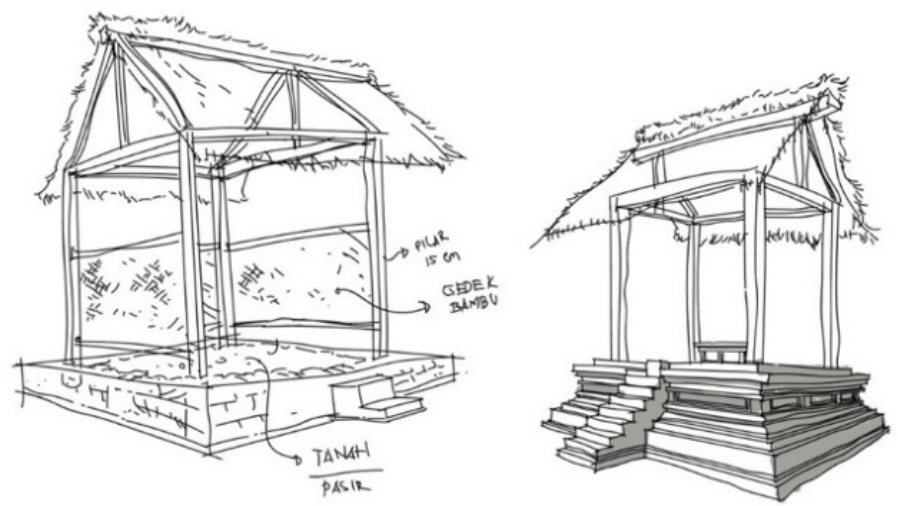

Gambar 16 Sketsa awal pola rekonstruksi punden utama peribadatan Situs Liyangan

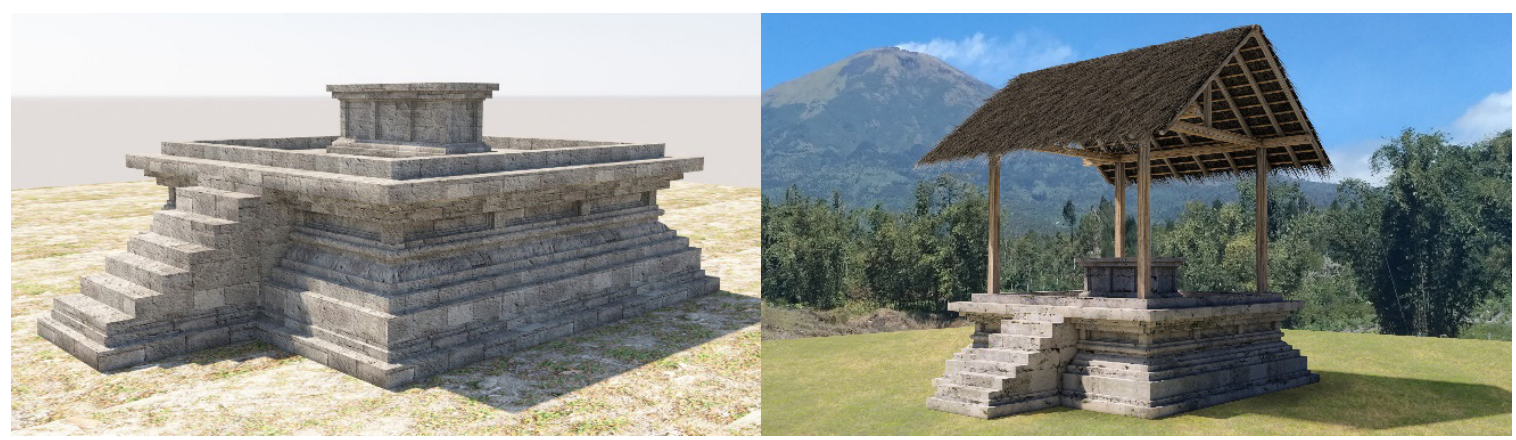

Gambar 17 Rekonstruksi punden utama dan pendamping atau batur peribadatan Situs Liyangan

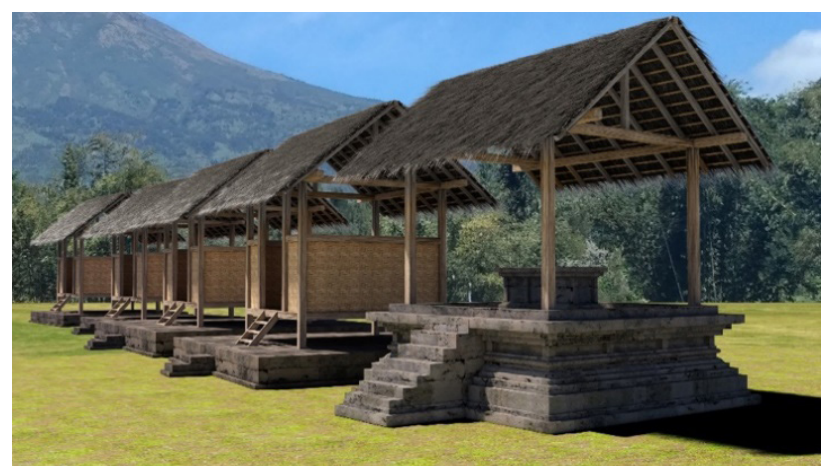

Gambar 18 Rekonstruksi bangunan punden utama dan punden pendamping dengan dinding anyam bamboo (gedeg) 


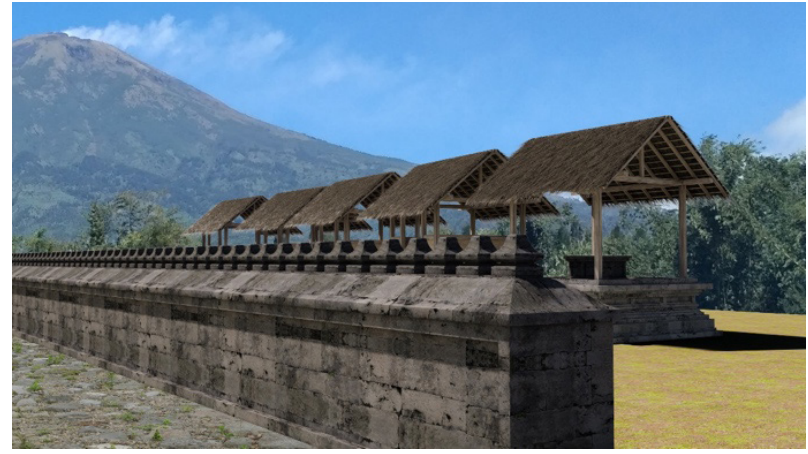

Gambar 19 Bangunan peribadatan terlihat dari pagar kompleks Situs Liyangan

Kompleks Situs Liyangan tidak hanya terdapat area peribadatan, tetapi terdapat pula area pertanian dan area pemukiman. Pemukiman tersebut merupakan pemukiman elit yang diperuntukkan khusus bagi para resi dan orang yang merawat area peribadatan. Pemukiman tersebut terbuat dari struktur kayu bambu dan ijuk sebgai bahan material bangunan. Hal ini diperkuat dalam temuan artefak di sekitar area pertanian yang merupakan bongkahan susunan kayu dalam struktur bangunan rumah.

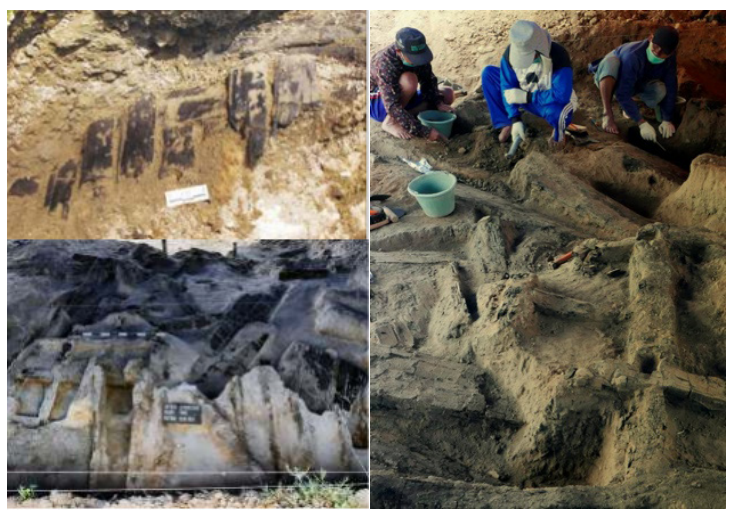

Gambar 20 Temuan artefak kayu, bamboo, dan ijuk

Berdasarkan temuan tersebut dipastikan bahwa struktur hunian di pilar dan dinding menggunakan kayu balok dan papan kayu dengan susunan pengunci (dowel) serta tumpukan ijuk sebagai atap hunian. Hunian ini merupakan hunian yang memiliki pola atap yang sederhana dan tidak menerapkan atap joglo meskipun berada diwilayah Jawa, hunian ini telah diperhitungkan dari bobot konstruksi atap yang ringan.
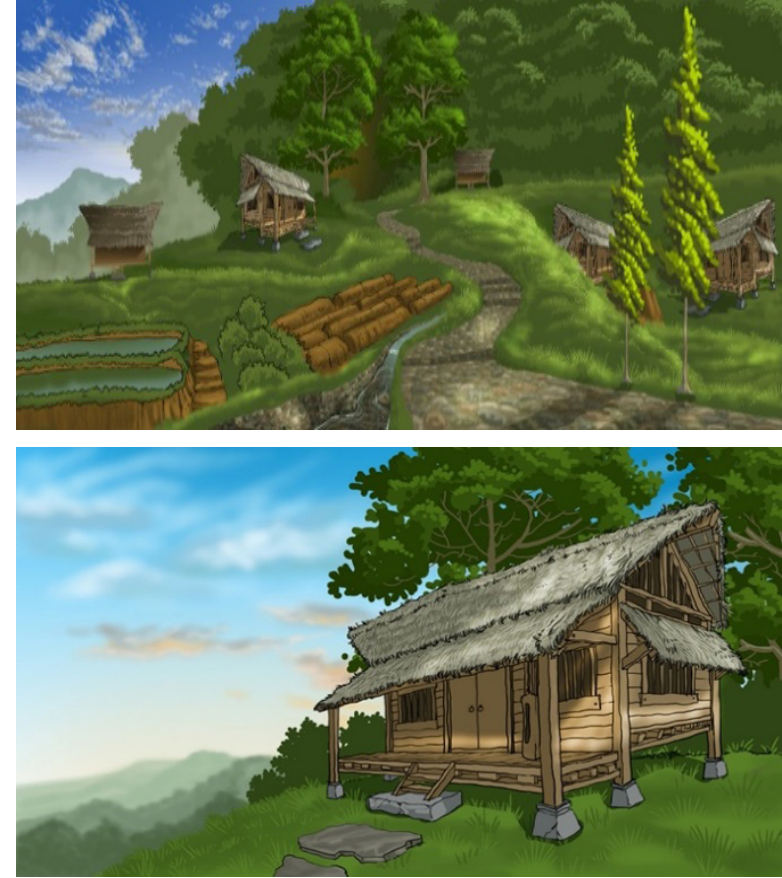

Gambar 21 Gambar hunian kuno area pemukiman Situs Liyangan

Proses pemvisualan gambar awal dari hunian tersebut menjadi acuan dalam permodelan 3D. Dengan demikian, dapat mengukur unsur material yang digunakan serta jumlah poligonal yang digunakan dalam topologi 3D.
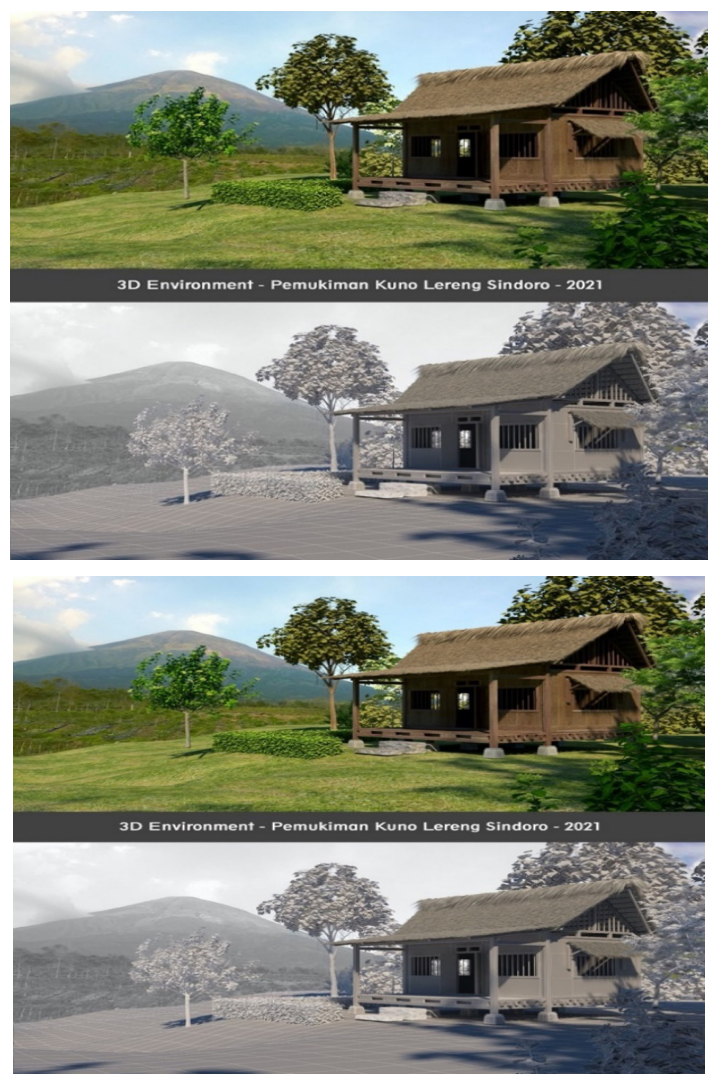

Gambar 22 Proses poligonal

dan hasil rendering dari hunian Situs Liyangan 


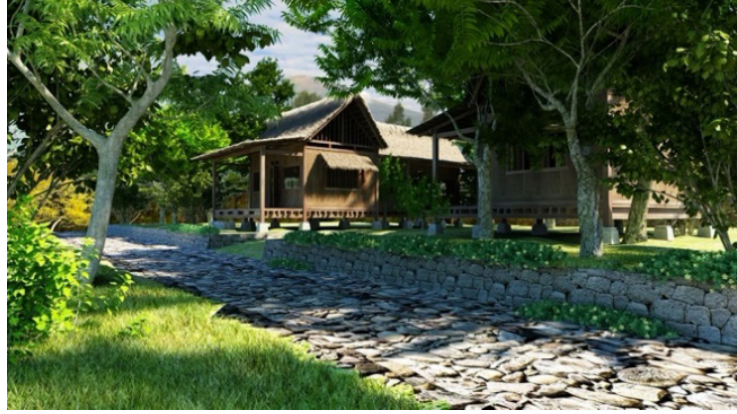

Gambar 23 Hasil rendering dari area pemukiman Situs Liyangan

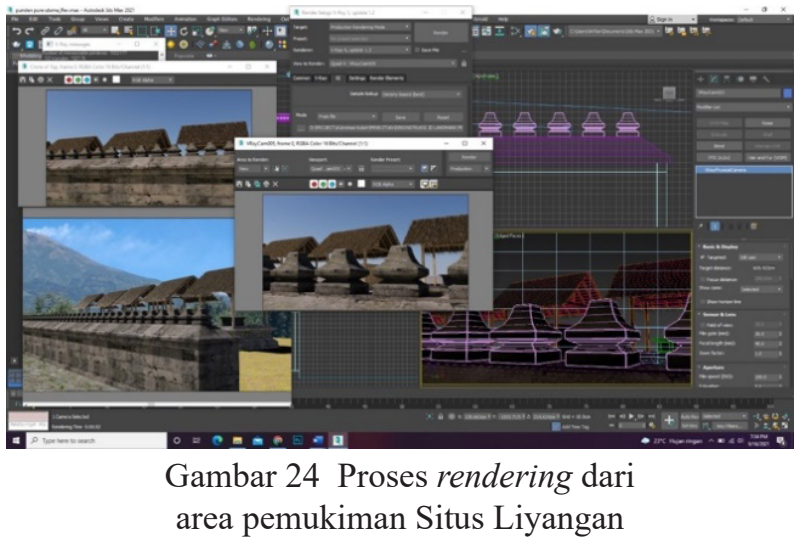

Seluruh proses pemvisualan rekonstruksi hunian kuno dan peribadatan tercapai berdasarkan hasil evaluasi arkeologis dari para arkeolog di Balai Arkeologi DIY. Visualisasi bangunan peribadatan dan hunian di Liyangan dinyatakan lebih tua daripada situs yang ada di sekitarnya, yaitu Candi Dharmasala yang berada di kompleks Candi Dieng. Kemiripan Situs Liyangan dengan Candi Dharmasala adalah temuan elemen batu, kayu, dan ijuk dari keduanya. Akan tetapi, di Situs Liyangan ada tambahan elemen temuan, yaitu bambu yang ditemukan di sekitar petirtaan. Situs Liyangan dinyatakan lebih tua daripada Candi Dharmasala karena di Situs Liyangan tidak ditemukan adanya sistem relief seperti candi-candi di kompleks Candi Dieng.

\section{SIMPULAN}

Proses penciptaan rekonstruksi 3D landmark Situs Liyangan dilakukan dengan kerangka kerja proses pengumpulan data arkeologis di Balai Arkeologi DIY dan di Situs Liyangan. Proses pengerjaan rekonstruksi visualisasi menggunakan software 3DMax. Pemvisualan rekonstruksi terukur dan berhasil berdasarkan dari sisi persepsi arkeologi, dengan bukti bukti situs-situs yang mendampingi pada era yang sama dengan di Candi Dieng. Situs Liyangan dinyatakan lebih tua daripada situs yang ada di sekitarnya, yaitu Candi Dharmasala yang berada di kompleks Candi Dieng. Disimpulkan bahwa Candi Liyangan lebih tua daripada Candi Dharmasala karena belum menerapkan sistem relief seperti Candi Dieng. Hasil pengumpulan data dari buku referensi di Balai Arkeologi dan pengamatan di lapangan, proses rekonstruksi Situs Liyangan dinyatakan berhasil sesuai bukti persepsi arkeologi tersebut.

\section{KEPUSTAKAAN}

Agosti, M., Ferro, N., Orio, N., \& Ponchia, C. (2014). CULTURA outcomes for improving the user's engagement with cultural heritage collections. Procedia Computer Science, 38(C), 34-39. https://doi.org/10.1016/j.procs.2014.10.007

Alberts, G., Went, M., \& Jansma, R. (2017). Archaeology of the Amsterdam digital city; why digital data are dynamic and should be treated accordingly. Internet Histories, 1(1-2), 146-159. https://doi.org/10.1080/24701475.2 017.1309852

Beel, D. E., Wallace, C. D., Webster, G., Nguyen, H., Tait, E., Macleod, M., \& Mellish, C. (2017). Cultural resilience: The production of rural community heritage, digital archives and the role of volunteers. Journal of Rural Studies, 54, 459-468. $\quad$ https://doi.org/10.1016/j. jrurstud.2015.05.002

Beel, D., Wallace, C., Webster, G., \& Nguyen, H. (2015). The Geographies of Community History Digital Archives in Rural Scotland. Scottish Geographical Journal, 131(3-4), 201-211. https://doi.org/10.1080/14702541.2 014.980839

Calin, M., Damian, G., Popescu, T., Manea, R., Erghelegiu, B., \& Salagean, T. (2015). 3D Modeling for Digital Preservation of Romanian Heritage Monuments. Agriculture and Agricultural Science Procedia, 6, 421-428. https://doi.org/10.1016/j.aaspro.2015.08.111

Galani, A., \& Kidd, J. (2019). Evaluating Digital 
Cultural Heritage "In the wild": the Case For Reflexivity. Journal on Computing and Cultural Heritage, 12(1), 138-155.

Hanan, H., Suwardhi, D., Nurhasanah, T., \& Bukit, E. S. (2015). Batak Toba Cultural Heritage and Close-range Photogrammetry. Procedia Social and Behavioral Sciences, 184(August 2014), 187-195. https://doi.org/10.1016/j. sbspro.2015.05.079

Ioannides, M., \& Quak, E. (2014). 3D Research Challenges in Cultural Heritage - A Roadmap in Digital Heritage Preservation, Lecture Notes in Computer Science 8355. Springer. https://doi.org/10.1007/978-3-662-44630-0

Lusenet, Y. De. (2007). Tending the garden or harvesting the fields: Digital preservation and the UNESCO Charter on the preservation of digital. Library Trends, 56(1), 164-182.

Nasional, P. P. A. (2020). Rencana Strategis Pusat Penelitian Arkeologi Nasional 2020-2024. Kementerian Pendidikan dan Kebudayaan.

Opitz, R., Mogetta, M., \& Terrenato, N. (2018). A Mid-Republican House from Gabii. University of Michigan Press. https://doi.org/http:// dx.doi.org/10.3998/mpub.9231782

Opitz, Rachel. (2018). Publishing Archaeological Excavations at the Digital Turn. Journal of Field Archaeology, 43(sup1), S68-S82. https://doi.org/10.1080/00934690.2018.1505 409

Rashid, M. S. A. (2015). Understanding the Past for a Sustainable Future: Cultural Mapping of Malay Heritage. Procedia - Social and Behavioral Sciences, 170, 10-17. https://doi. org/10.1016/j.sbspro.2015.01.007

Rokhani, U., Salam, A., \& Rochani-Adi, I. (2016). Rekonstruksi Identitas Ke-"Tionghoa"-an dalam Film Indie Pasca-Suharto. REKAM: Jurnal Fotografi, Televisi, dan Animasi, 12(1), 55. https://doi.org/10.24821/rekam. v12i1.1380

Tanudirjo, D. A., Yuwono, J. S. E., \& Wardoyo Adi, A. M. (2019). Lanskap Spiritual Situs Liyangan. Berkala Arkeologi, 39(2), 97-120. https://doi.org/10.30883/jba.v39i2.474
Tiga, R., Relief, D., Prasetya, D. A., Soesanti, I., \& Hartanto, R. (2010). Menggunakan Segmentasi Grayscale Citra Dua Dimensi. 128-135.

Wibisono, A. B., Artanto, A. T., \& Ayuswantana, A. C. (2021). Fotografi sebagai Rekonstruksi Visual dalam Seni Bercerita Rakyat Studi Kasus "Sarip Tambak Oso." Rekam, 17(1), 1-12. https://doi.org/10.24821/rekam. v17i1.4940 